\title{
Management Transformation in the former Soviet Union - Estonian managers evaluate past and forthcoming transition ${ }^{*}$
}

\author{
Kari Liuhto $^{* *}$
}

A successful accomplishment of an economic transition does not depend only upon a functioning economic policy but, first and foremost, upon enterprise managers' ability to adapt to the new economic conditions. Enterprise managers are ultimately responsible for the realisation of macro-economic reforms in practice. Therefore, the research should be increasingly focused on the micro-economic transformation. This article describes managerial transformation in Estonia in the 1990s. As Estonia has carried out its macroeconomic transformation most successfully among the post-Soviet republics, Estonian managers' views could provide guidelines for the evaluation of the management transformation in other parts of the former Soviet Union.

Die erfolgreiche Bewältigung des ökonomischen Transformationsprozesses hängt nicht allein von einer effizienten Wirtschaftspolitik $a b$, sondern und vor allem von der Fähigkeit der Manager in den Betrieben, sich an die neuen ökonomischen Bedingungen anzupassen. Sie sind letzten Endes verantwortlich für die Umsetzung der makroökonomischen Reformen in der Praxis. Aus diesem Grunde sollte sich die Forschung vermehrt auf die mikroökonomischen Aspekte des Transformationsprozesses konzentrieren. Der vorliegende Artikel beschreibt die Transformation auf der Managementebene in Estland in den 90er-Jahren. Vor dem Hintergrund der Tatsache, daß Estland bei der makroökonomischen Transformation von allen Post-Sowjetrepubliken am erfolgreichsten war, kann die Sicht der estnischen Manager auch gewisse Hinweise geben für die Evaluation der Transformation auf der Managementebene in anderen Nachfolgestaaten der ehemaligen Sowjetunion.

Manuscript received: 01.04.1996, revised: 28.06.1996, accepted: 07.07.1996.

** Kari Liuhto, born 1967, Senior researcher at the Institute for East-West Trade at the Turku School of Economics and Business Administration, major areas of research interest: entrepreneurial and managerial transformation, and foreign direct investments in the former Soviet Union. 


\section{Research framework}

The research framework consists of two parts. The first part describes the formation of the organisation management and integrates it into the organisational and managerial efficiency. The second part covers some of the major weaknesses of the Soviet managers concerning their adaptation to a market economy. With this dual approach one tries to explain why the particular management areas were chosen for analysis in this research.

The basis of enterprise management is the organisational mission. According to Rue and Holland (1989:7), the mission of the organisation is the widest and highest level of organisation's objectives. Through its mission, the organisation determines the reason for its existence. Gradually managerial practices begin to build up around the mission of the organisation. Among the most important managerial practices is the creation of corporate strategy. Andrews (1980:18) defines corporate strategy as ,the pattern of decisions in a company that determines and reveals its objectives, purposes and goals, produces principal policies and plans for achieving those goals ...".

The corporate strategy functions as a link between the organisational mission and the operative management practices. Managerial efficiency is determined by how effectively the strategic and operative management can integrated both to one another and to the opportunities provided by the external management environment (Tung 1986:233-247).

Previous studies have indicated that Soviet companies suffered from various management problems which decreased the efficiency of Soviet companies. Shortcomings were detected in business idea thinking and strategic management. The existence of these weaknesses is not surprising because the Soviet enterprise management had no responsibility for these management areas (Minzberg 1992:335). Organisations' business ideas were determined by the political system and ministries (Milner et al. 1986:16-60). Even the most massive Soviet companies functioned as non-independent production units of the whole Soviet economy (Kozminski 1993:7).

Earlier researches have also pointed to several deficiencies among Soviet managers when operative management was concerned. Soviet managers are often blamed of low degree of motivation and low commitment to their company's operations (Nurmi / Üksvarav 1994:58). In addition, previous research results indicated weaknesses in the Soviet managers' skills. These weaknesses resulted from the deficient Soviet education and training system which placed more emphasis on teaching technical skills and management theories than developing practical business know-how (Beissinger 1988:221239). Therefore, it is hardly surprising that Soviet managers were seen to have lacking knowledge, for instance, on their customer-orientation and opportunity cost thinking (Liuhto 1991:106). 
Besides management knowledge, there seemed to be room for improvement in Soviet managerial style. The Soviet managers have been blamed that they treated subordinates as extensions of machines. In addition, Soviet managerial style is very often characterised as authoritarian (Lawrence / Vlachoutsicos 1990:272-286, Krips 1992:130-144). Previous studies have also illuminated various organisational problems in Soviet companies. These problems are illustrated, for instance, in stealing company property, unauthorised absence from work and use of alcohol at work (Liuhto 1993:15). These malpractices often resulted in overemphasis on control, written orders and overextensive bureaucracy of the Soviet system which lead to the organisational immobility (Lawrence / Vlachoutsicos 1990:272-286).

Immobility was further increased by the Soviet managers' reluctance to develop the company operations. For example, Soviet managers were not interested in improving production because it consumed a lot of the company's resources and thus endangered the implementation of the state plans (Berliner 1988:277-285). Gradually product development and change as a whole became hazards that must be avoided. Because of this avoidance of change, Soviet management can be characterised as a status quo management culture. The following figure summarises the research framework of this study (e.g. Figure 1).

Figure 1: The operational framework of this study

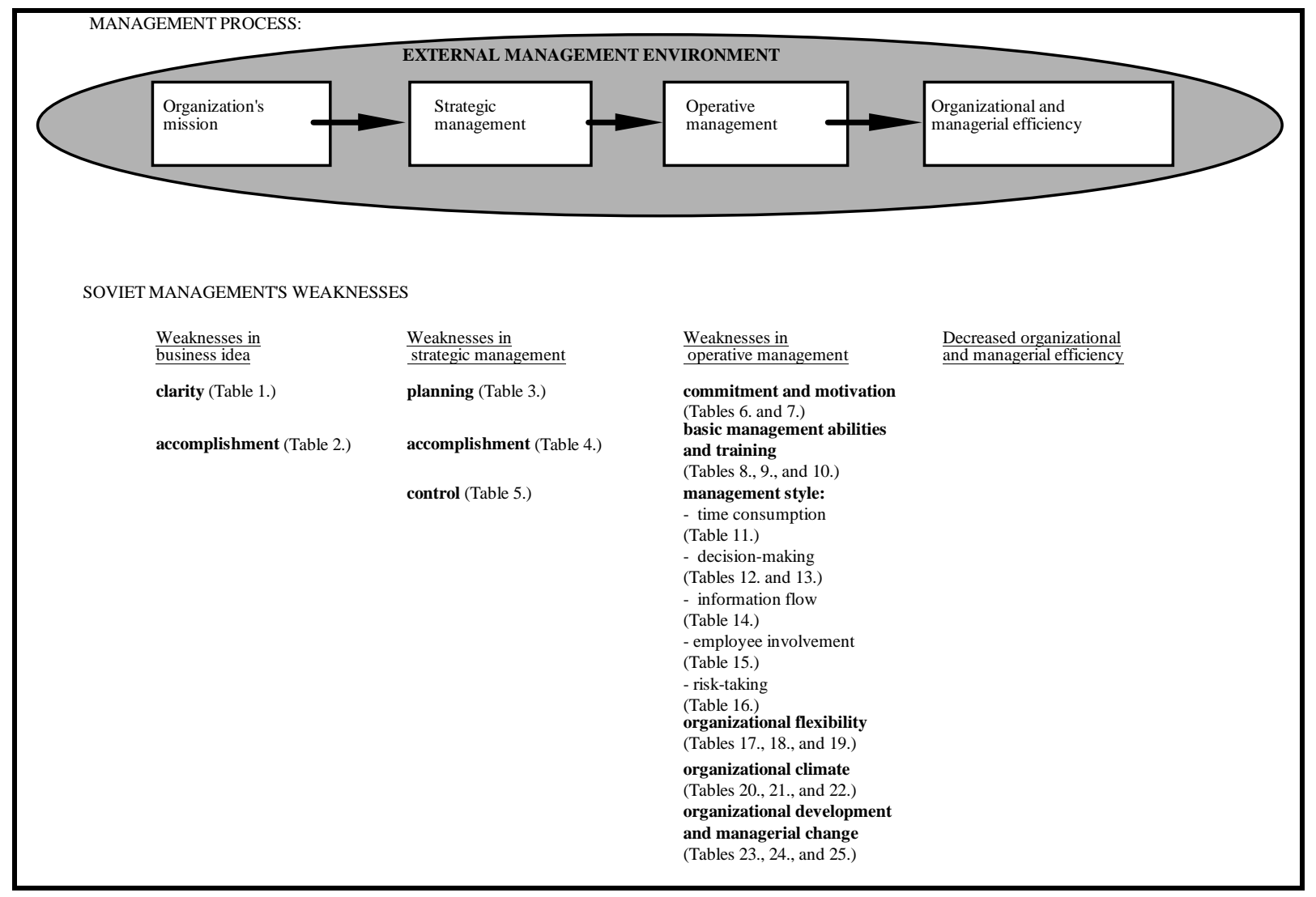




\section{Research method and sample}

The managers participating in this study were asked to evaluate the state of their company's management during three different periods of time: on the eve of the disintegration of the former Soviet Union (1991), in 1995, and at the end of this millenium (1999). In this context one needs to underline that this particular method may produce slight distortion. First, the evaluation of the transformation accomplished so far may indicate more of managers' attitudes toward it than what actually took place in reality. Second, estimates on forthcoming transformation may represent more managers' hopes than reality.

Despite the possibility of slight distortion of the data, the method described above was an optimal alternative to collect information on the management transformation in Estonia as the research timetable did not allow researcher to wait research results for almost ten years. In the future, however, it is wellgrounded to repeat the study.

Besides the repetition of the research, an interesting addition would be an inclusion of an outsider's point of view on the transformation. In other words to study how foreign managers operating in Estonia consider the management transformation in Estonian organisations. Similarly, comparative studies between former Soviet republics might widen the perspective into the managerial transformation from the planned into market economy.

In this research, Estonian management was studied through 25 questions. The questions on the management transition are based on a seven-point scale. The seven-point scale reveals transition more effectively than a five-point scale. This simply stems from the respondents having to mark three evaluations to each of the questions. The tables presented in the following section contain scales in which 1 means 'extremely good', 2 'very good', 3 'good', 4 'average', 5 'poor', 6 'very poor', and 7 'extremely poor'.

Over one per cent of the operating companies (300) in Estonia were selected for the research. The selection was difficult as it was hard to find a representative sample. This problem originates in the Estonian statistics, which offer fairly distorted data because non-business organisations are registered in the enterprise statistics. Besides the deficient statistics, one must underline the fact that the operating companies represent only some 30 per cent of all the registered organisations in Estonia (Liuhto 1996a:126-127).

As the random sampling would have been an irrational method for the data collection, the sample was chosen in a different manner. First, 300 companies were cross tabulated so that they represented the entire organisation field of Estonia in terms of their industry and geographical location. After this, the task of an Estonian expert was to search 300 companies whose size and ownership would represent the organisation statistics of Estonia as closely as possible. In addition, the enterprises were selected so that 3-5 per cent of their managers 
would be ethnically Russians. Furthermore, the sample was intended to contain some 15 per cent of foreign-owned companies, which corresponds to their share from all the operating companies in Estonia (Liuhto 1996a:128).

The inquiry was conducted during the first half of 1995 . The questionnaires were sent in March-April and the last questionnaire was returned in July 1995. Regardless of the reminders, only 114 questionnaires were answered and returned (return percentage was 38).

The loss percentage was particularly high when small enterprises were concerned. The major reason behind this might have been their fear for misuse of data and the increasing organised crime in Estonia. Similarly to small enterprises, the majority of trade companies did not return the questionnaire. One explanation may be that the majority of the Estonian organisations registered in trade did not operate. While trade and services were underrepresented, industries in or related to manufacturing became overrepresented. However, the fact that capital-intensive enterprises were overrepresented may produce even more interesting results because a successful transition of industrial enterprises constructs the foundation for the successful implementation of the overall economic transition.

While analysing the structure of ownership in the studied companies, nearly half of them were under private ownership (48\%). The share of state and municipally-owned companies was slightly below one third (32\%). One fifth of the companies were owned by juridical persons (20\%). The studied companies were considerably more often owned by the state or municipalities than the organisation field as a whole. The large share of state or municipal companies stems from the fact that the sample consisted of a large group of industrial enterprises, which are in many cases still in state ownership. Foreign ownership existed in 26 companies, which represents over one fifth of the sample.

Most of the managers who participated in the study were either general directors or managing directors (77\%). The share of the middle management was slightly less than a quarter (23\%). More than 70 per cent of managers had operated in a management position already during the Soviet era. The majority of the managers were ethnically Estonians (97\%).

\section{Managerial transition in Estonia in the 1990s}

Enterprise management in the former Soviet Union has been criticised for a lack of business idea thinking. However, the Estonian managers seem to feel that the clarity of their business idea was not 'poor' in 1991. On the basis of this research data it is impossible to state whether Western studies have underestimated the Soviet managers' concept of the clarity of their business idea or whether these Estonian managers are too optimistic when evaluating the clarity of their business idea. 
Nevertheless, most important is that the Estonian managers believe that their business idea had become clearer since the last Soviet year until 1995. The reason for this positive development may be that an increasing competition is forcing managers to crystallise their business idea. One should point out that only those managers who had already operated during the Soviet era saw some depreciation in business idea from 1991 till 1995. The reason for this might have been the 'old Soviet' managers' greater difficulties in adjusting to the changed business environment than their 'new' manager colleagues.

Positive, in terms of the future, was that the clarity of business idea is considered better than 'good' in 1999. Based on the data, the unclarity of business idea will not impede the efficiency in the management of Estonian companies during the latter half of this decade. A factor with at least a similar weight than the clarity of business idea was the way in which managers implement it. The data suggest that the accomplishment and clarity of business idea were at the same level in 1995. However, one should view these answers with some cautiousness. In other words, is the transformation as great in reality than the Estonian managers themselves believe?

Any significant differences could not be found in the transformation pace of the clarity of business idea and its accomplishment between the Estonian and the foreign-owned companies. This is quite a surprising finding as many foreign managers working in Estonia assume that the foreign management practices accelerate the management transformation. Furthermore, the comparison of the private and state enterprises did not uncover any significant differences. This research result indicates that the privatisation of the company does not necessarily increase its management's adaptability to the market conditions (e.g. Tables 1 and 2) ${ }^{1}$.

Table 1: The clarity of your company's business idea

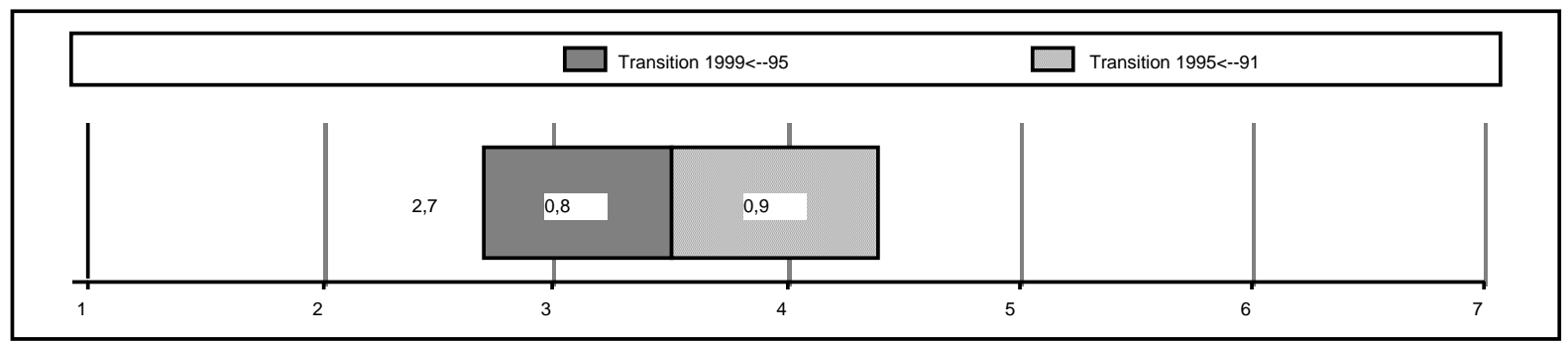

The Estonian managers were rather dissatisfied with the state of strategic planning in 1991. This does not come as a surprise since previous studies have already underlined the fact that strategic management was beyond the responsibility of the Soviet enterprise management. Fortunately, the state of

1 Pearson's chi-square test was used when the companies were compared. 
strategic planning is estimated to improve considerably during this decade. The Estonian managers expected strategic planning to be better than 'good' in 1999.

Table 2: The accomplishment of the business idea

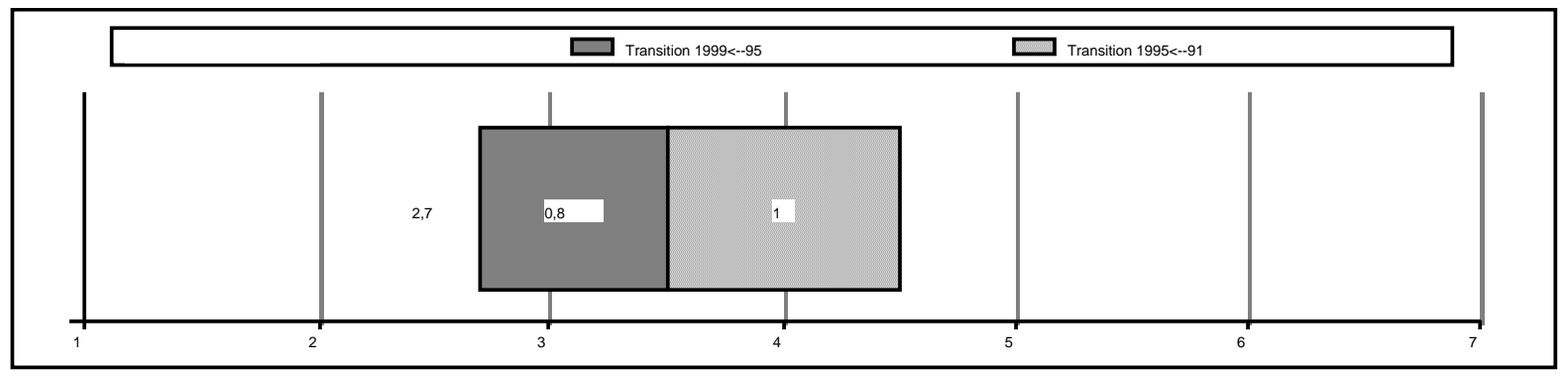

The Estonian managers' estimates suggest that the accomplishment and the control of strategic plans fell a bit short of the level of planning in 1995. These differences are not acute enough to endanger the strategic management as a whole. A positive feature is that as a result of faster transformation the accomplishment of strategies and its control are expected to have reached the level of strategic planning by the end of this decade.

To summarize the strategic management in Estonian companies, one can state that it is not a stumbling block of Estonian enterprise management. The answers given by the Estonian managers seem to suggest that managerial transformation has occurred faster than many Western experts were able to predict. In the background of this managerial transformation is at least partly the fact that these studied companies have invested strongly on the training of their managers.

The ownership, the industry or manager's ethnical background did not reveal significant differences between the companies. One might have anticipated that considerable differences would have appeared especially when so called modern industries (computer business and banking) were compared with more traditional ones (agriculture and forestry). Small distinction in the management transition between these industries might be explained by the possible bias caused by the low number of the studied companies or simply by the fact that industrial classifications are not best way to analyse the real activities of the enterprises. In order to find firm explanation for this, further study is required (e.g. Tables 3, 4, and 5).

Table 3: The planning of company strategies

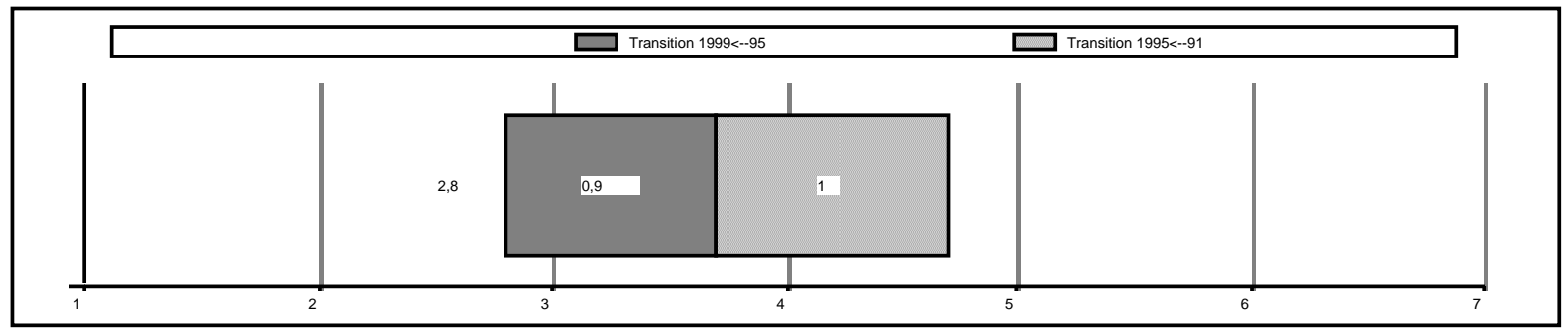


Table 4: The accomplishment of company strategies

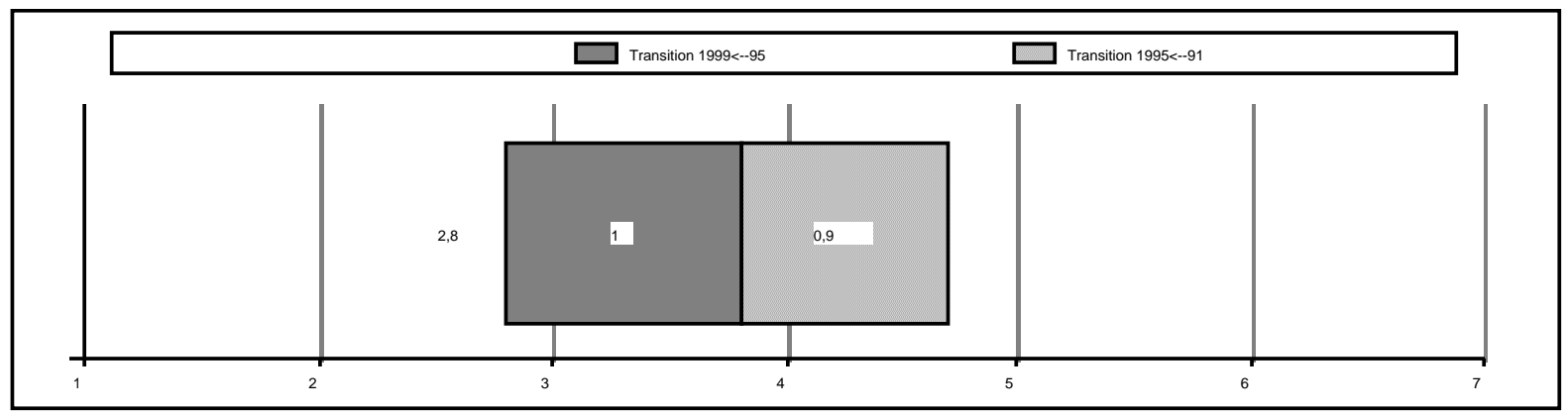

Table 5: The control of the accomplishment of strategies

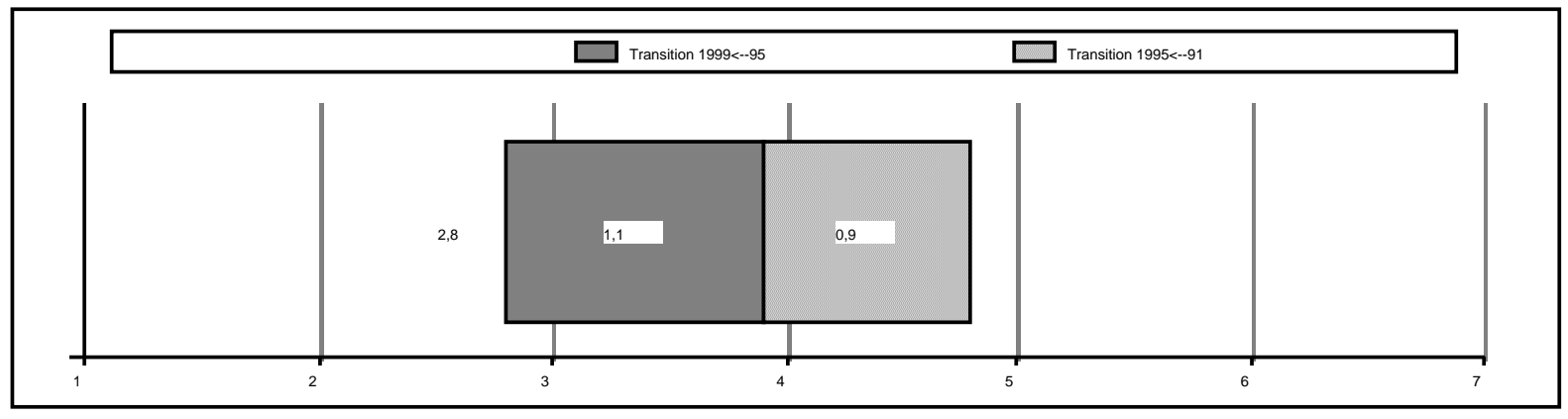

The Estonian managers believe that the commitment of managers to goals was rather satisfactory already in 1991. This is an unexpected result since the commitment of Soviet managers to the company goals was not usually considered flattering. In this context, one needs to mention that the requirements for 'equal wage policy' gradually disappeared from the Soviet Union after the Perestroika. The wage liberalisation might have been one factor that increased the commitment of the Soviet managers. Therefore, one should not generalise the level of the commitment in 1991 to the whole Soviet era.

The Estonian managers believe commitment will improve during this decade. In the background of managers' increasing commitment may simply be more meaningful jobs and increasing salaries, which usually increase the level of commitment. Besides these obvious explanations, one should also remember that the growing sense of national identity among Estonian managers may likewise increase the level of commitment to the company goals ${ }^{2}$. Estonian managers may manifest national spirit in the 'reconstruction' of Estonia and hence become more committed to the company, through which they can now concretely participate in this vast reconstruction project.

The development of managers' commitment resembles largely the transformation of managers' motivation. The Estonian managers did not give flattering estimates how they were motivated in 1991. Although the motivation level of Estonian managers seems lacking, improvement has taken place since

2 See Liuhto (1996b). 
1991. Motivation is believed to further improve during the latter half of this decade.

One of the reasons for such a belief may derive from competition which is forcing Estonian companies to invest in motivating their managers; otherwise Estonian companies may be threatened by losing their best managers to competitors. Secondly, the growing degree of motivation may reflect the fact that Estonian companies are more and more appreciating the importance of human resources in terms of competitive position ${ }^{3}$. All in all, the Estonian managers believe that the motivation of managers will be better than 'good' by 1999.

It was interesting to notice that the motivation of the managers has improved significantly faster in state companies than in private ones. An explanation for this development is the lower starting point of the state-owned companies which 'exaggerates' the force of the change. The faster transformation pace does not mean, however, that the current motivation level in the state-owned companies would be better than in the private ones.

Second significant finding was that the foreign companies have managed to motivate their managers better than locally-owned. One factor behind the more rapid transformation and higher motivation level of managers can be due to the fact that the foreign companies put more emphasis on the personnel policy. Second explanation might simply be the better financial position of the foreign companies which allows them a better basis to motivate their managers.

The data might lead one to assume that there are no severe weaknesses in the degree of managers' commitment to company tasks and motivation. If this selfevaluation is not distorted, it gives a good opportunity for the Estonian companies to use efficiently their human resources, which is one of the most valuable 'natural resource' of Estonia. In the same context, one should not forget how easy it is to evaluate one's own degree of commitment and motivation slightly overoptimistically. This is indicated by the comments of foreign managers operating in Estonia with regard to the commitment and motivation of their Estonian colleagues, the older managers, in particular (e.g. Tables 6 and 7).

The analysis of management's market-orientation indicates that it will improve most during this decade. The transformation has been much faster in the state enterprises than in the private ones. Nearly a half of the managers in the state companies felt that market-orientation has improved two units (or more) between 1991 and 1995. Only ten per cent of the managers in private enterprises felt the same. The reason for the fast development in state-owned companies is their lower starting point which 'artificially' increases the transition pace.

3 This is also referred to by an earlier study on Estonian managers (Ariko MG, 1994). 
Table 6: The commitment of managers to company goals

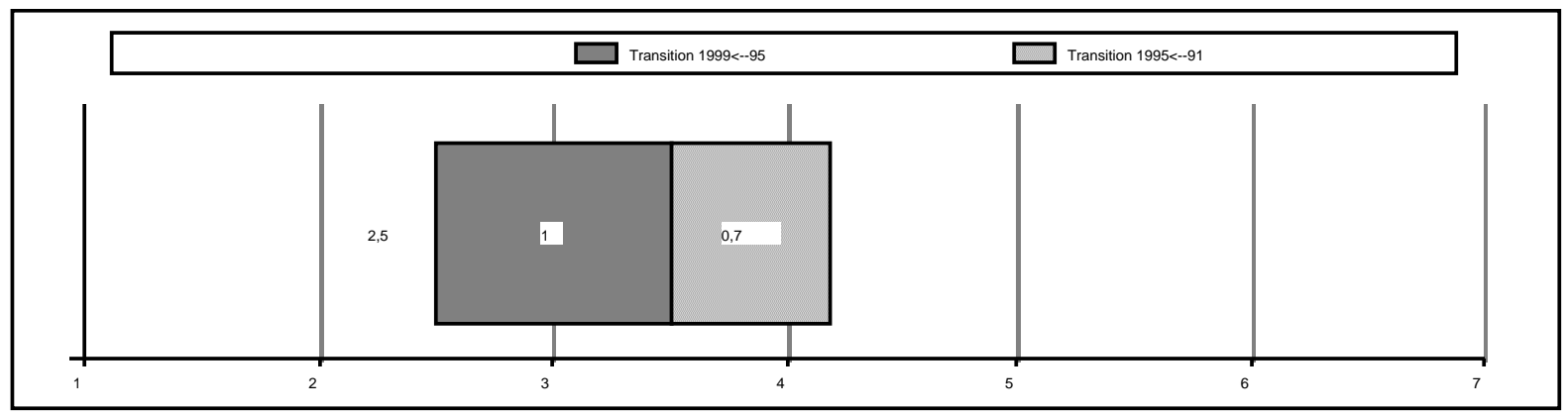

Table 7: The motivation of managers

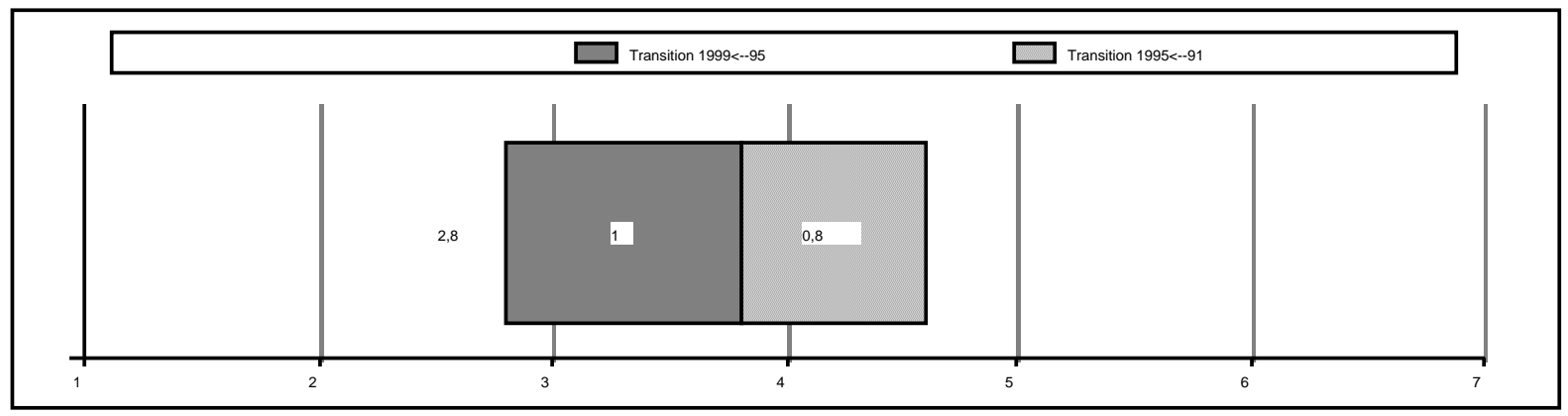

The engines of increasing market-orientation will be the Estonian-owned companies. This was supported by the fact that only less than five per cent of the managers in the foreign-owned organisations believe in the improvement during the second half of the decade. The corresponding share among the locally-owned companies is three times higher. All in all, the data indicates that market-orientation would be better than 'good' by 1999 .

Whether Estonian managers have become more market-oriented in reality or their views are overoptimistic, is difficult to answer. Personal observations made by the researcher concerning the Estonian service and trade sector indicate that customer and market awareness have clearly improved since the Soviet years. A smaller change has occurred in industrial enterprises, whose managers are often more interested in production than marketing.

Cost-awareness of management has almost transformed in a similar manner to market-orientation. The improvement of cost-awareness was strongest in stateowned enterprises. This is not a surprise, as severe cuts in state funding introduced by the transformation have changed the daydream of the state companies into a financial nightmare. In private companies the situation has been different as they have been forced to operate without the state finance. In fact, some 60 per cent of the small and medium-sized private companies in Estonia are even outside the bank finance ${ }^{4}$. Estonian managers' estimates that cost-awareness will be better than 'good' by 1999 seem fairly reliable, because

4 See Kaubaleht (1995). 
Estonian managers have been obliged to pay attention to costs and their cause perhaps more than to any other subarea of management.

In addition to the managerial skills discussed above, it is of vital importance that the latest business know-how is passed to the Estonian managers. Therefore, it is a very positive sign that the studied enterprises have improved their training opportunities for their managers. Estonian managers estimate that managers' training opportunities will be better than good at the end of this decade. Watertight explanations are difficult to come by, but one explanation may simply be increasing competition and improving training services in the Estonian market.

Surprisingly, foreign ownership does not seem to fundamentally improve the training services provided in companies, even if it is generally believed that foreign owners bring their advanced training methods along with them. On the contrary, it is no surprise that companies operating in so called modern industries invest more in training than those in traditional ones. This is due to the fact that some of these modern industries did not even exist during the Soviet era.

Summa summarum, the data indicate that there were severe deficiencies in managerial know-how especially among the managers of the state companies in 1991. However, the managers of these companies feel that they have managed to strengthen their skills. If this situation also prevails in reality, it gives a positive impression on the future development of the Estonian economy. In this context, one needs to underline that managers' competence alone will not make companies competitive, but the skills of the entire personnel must be competitive, too (Tables 8, 9, and 10).

The Estonian managers estimated the efficiency of the manager's use of time in 1995 among the poorest management areas. The reason for the Estonian managers' inefficient use of time cannot be found either in the deficient economic infrastructure or business environment. The reason for inertia could be caused by the national management culture. In other words, even if the conditions within a company would enable efficient use of time, the prevailing national management culture could slow down managerial cultural transformation in more advanced companies. 
Table 8: Market-orientation in management

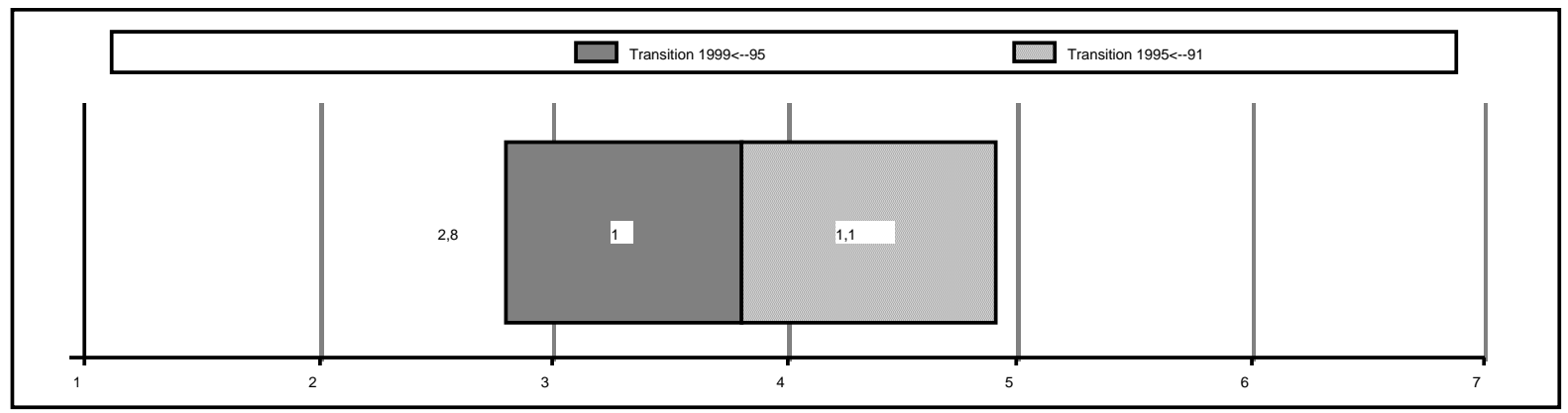

Table 9: Cost-awareness in management

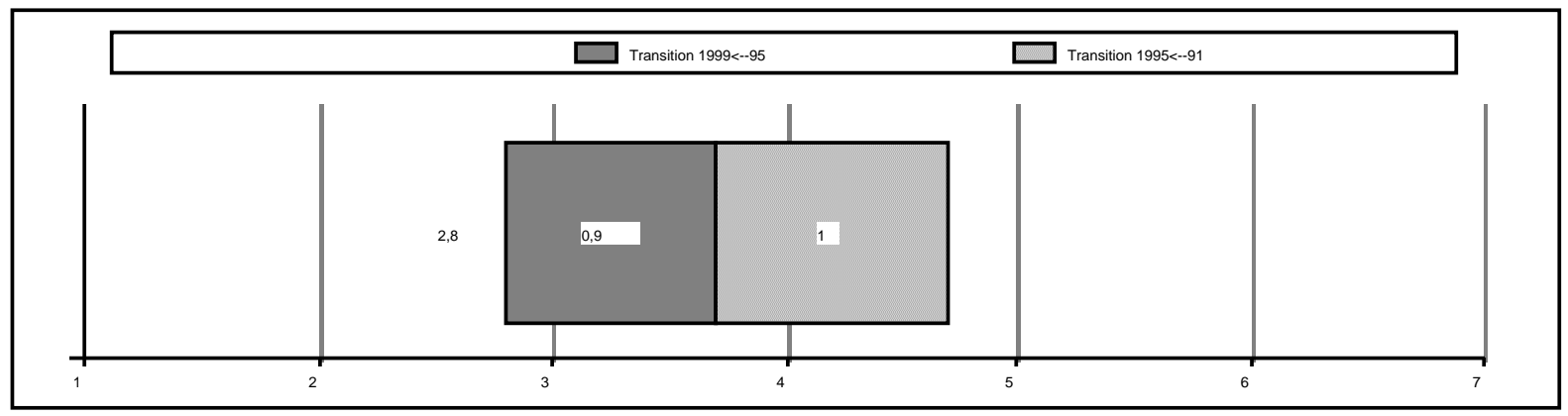

Table 10: The training opportunities for managers

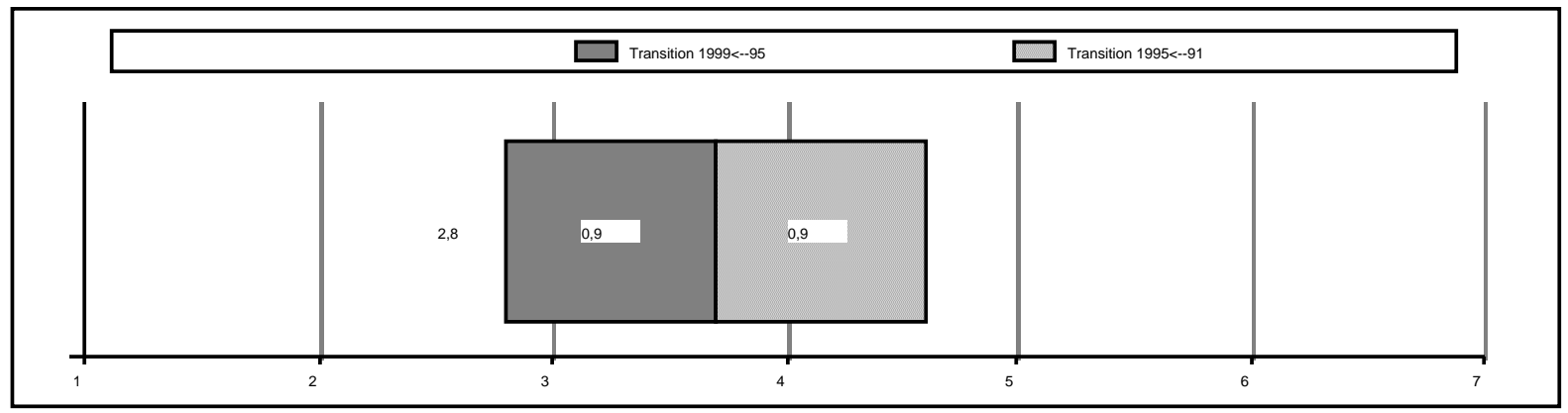

The Estonian managers expect their use of time to become more efficient during the latter half of this decade. In fact, they believe it to have risen better than 'good' by 1999. Three per cent of the companies expected the managers' use of time to deteriorate. These were all Estonian-owned companies whose managers held management positions already during the Soviet era. This might be a subtle indication of Soviet heritage causing some strain for the transformation of management.

According to Estonian experts, the inefficient time management of managers manifests, for instance, their reluctance to delegate certain routine tasks to their subordinates. As an illustration one expert mentioned that many managers still pay company invoices in person ${ }^{5}$. Not only does this behaviour model reflect managers' lack of confidence in their employees, but is a kind of relic from the

5 Based on the interview with Heino Tammiste, managing director of Enterprise Association of Pärnu, January 18th, 1996, in Pärnu, Estonia. 
Soviet time, when the general directors together with their head accountants dominated the financial transactions of the company (e.g. Table 11).

The estimations on the planning of decision-making in 1991 are worse than one could have anticipated. One could have prefigured that the planned economy would have taught Soviet managers all the secrets of planning. In this respect, one must remember that the Soviet planning system did not meet the requirements of planning in organisations operating in a market economy. This might be explanation why the Estonian managers evaluated the state of planning of decision-making in such a poor manner.

Table 11: The efficiency of the use of time by managers

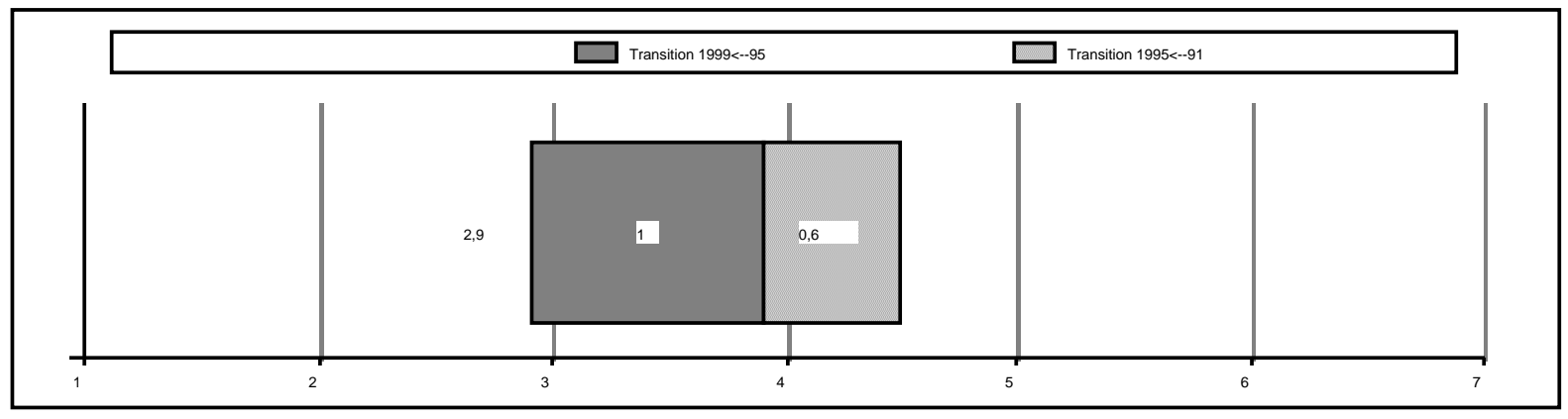

Another interesting observation is that in 1991 decisions were planned in a more systematic manner than strategies. This finding might lead one to assume that strategic management during the Soviet era was in a poorer shape than operative management. This is reasonable since strategic management in Soviet organisations was limited because ministries were responsible for strategic management. Positive, in management transformation, is that the gap between strategic and operative management is believed to disappear by 1999 .

The data suggests that Estonian decision-making can by no means be considered stagnant. In the same context, however, one must underline that the rapidness of decision-making may occasionally even turn against itself. This means that fast decisions are naturally not synonymous with correct decisions. On the other hand, slow decision-making might be the most catastrophical alternative for enterprises operating in the turbulent conditions of the transition economies

To summarise the decision-making, one can state that the Estonian managers believe it to be both systematic and fast. If this is true, at least Estonian companies will not suffer from the inability of their managers to know how to act and to act rapidly. Whether rapidness is a specific feature of Estonian decision-making could be illustrated better if it were compared with Russian, Nordic and American decision-making. On the basis of the current research material, one can only quess where to place the Estonian managers among other national management cultures (e.g. Tables 12 and 13). 
Table 12: The planning system of decision-making

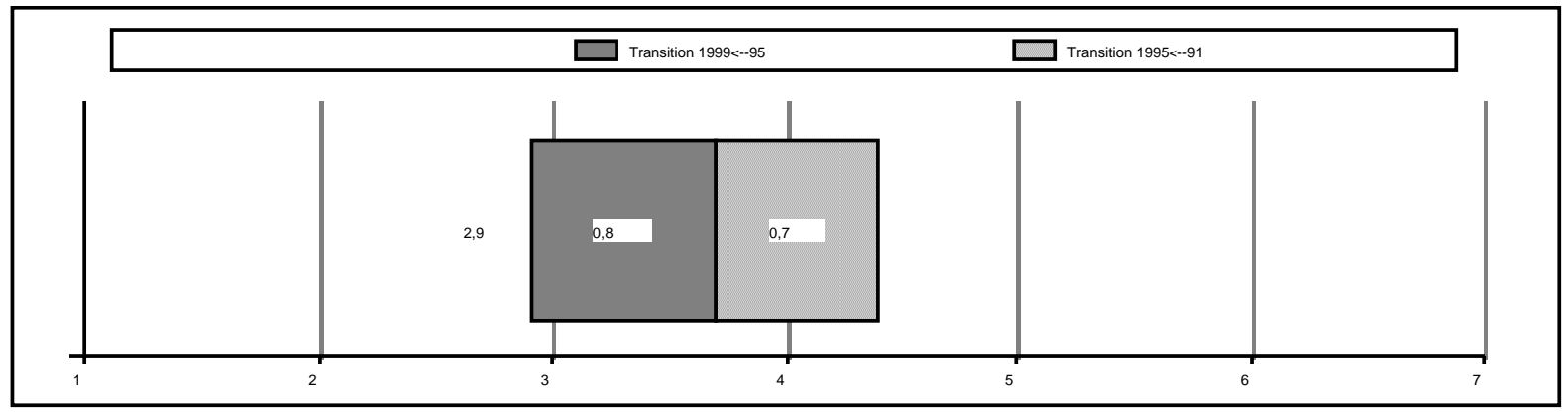

Table 13: The rapidness of decision-making

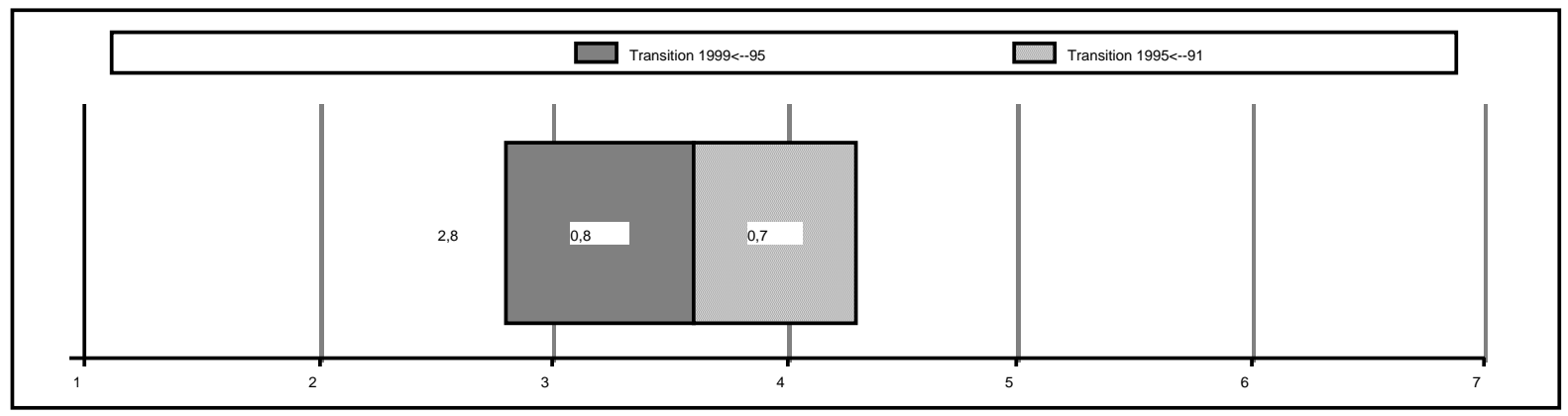

Soviet managers were many times accused of withholding information. The Estonian managers' views on the passing of information in 1991 indicate that this particular management field was not as problematic as commonly believed. While analysing the answers, one must remember that the majority of the managers in this study belonged to the upper management who had access to all the information channels. If the study had covered the views of the middle or supervisory management, the result would most probably have been lower.

All in all, the Estonian managers believe that the passing of information will have risen above the level of 'good' during the latter half of this decade. One must nevertheless remember that there will be no changes in the passing of information if the managers do not alter their ways of behaviour and thus the information policy of the entire company. As the end of this section will show, the Estonian managers are not too enthusiastic to change their ways, which can endanger the accomplishment of several reforms and the transformation ability of the entire company (e.g. Table 14).

Table 14: The passing of information in your company

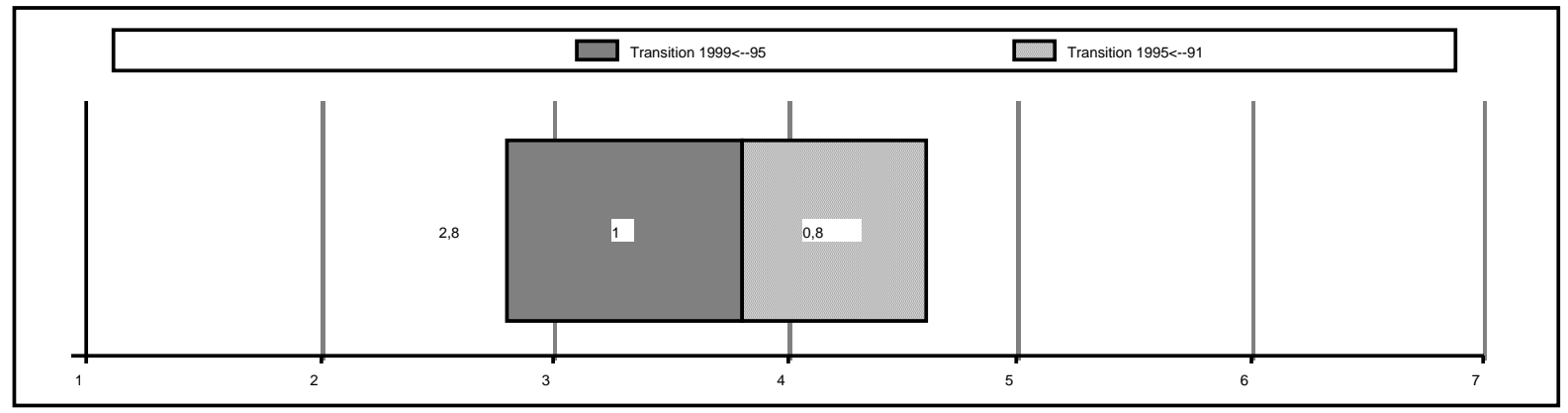


The data support the impression that during the Soviet era the employees had much less influence on their company operations than prescribed in the socialist ideology. This is not surprising as the chances of a Soviet worker to affect the company operations were only apparent, despite the official meetings. The power in the Soviet organisation was strongly centralised on the general manager, head accountant, technical manager and the official representative of the Communist party.

The managers believe the situation has improved and will continue to improve during the latter half of this decade. The managers believe that the employees' chances to influence will be better than 'good' by 1999. The strongest transformation is expected to occur in enterprises owned by the Estonian state.

On the other hand, it is difficult to believe in an unambiguous improvement of the situation. The employees will not have more power to influence without a fundamental strengthening of the Estonian trade union, which seems unlikely to happen in such a short period of time. No manager voluntarily dispenses his power to others unless convinced of its contribution to the efficiency of the organisation and thus to the strengthening of the manager's own position. And the increasing power of the trade union is unlikely to make the company operate more efficiently (e.g. Table 15).

Table 15: The employees' chances to influence in company

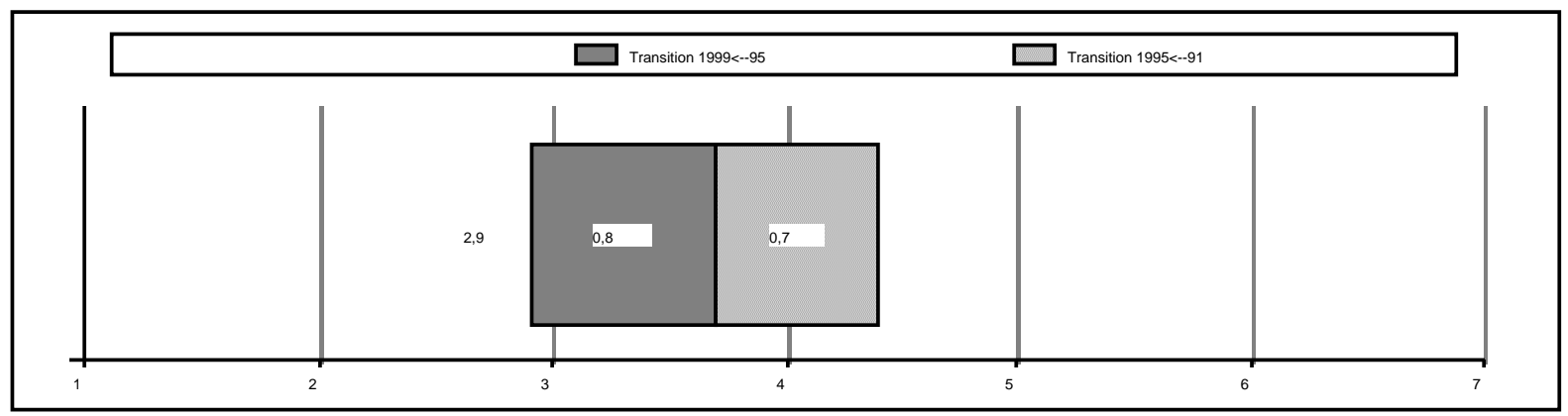

The estimates of the Estonian managers in 1995 suggest that the willingness of managers to take risks was satisfactory. However, the meaning is satisfactory in this context is relative. Naturally, one cannot conclude, on the basis of these findings, how the Estonian managers' risk-taking compares with other former Soviet colleagues or Western managers. Yet these findings seem to indicate that at least it cannot be regarded as risk avoidance, which was a typical characteristic of Soviet management.

Surprisingly, the data indicate that willingness to take risks has not transformed at different pace in the state and the private companies. Despite the similar transformation pace, risk-taking in private companies is still stronger than in state companies. This is due to the fact that the starting points were different. In this context, one has to underline again the illusionary nature of change i.e. 
change does not give any information on the starting point or the final outcome of the transformation, and hence, can lead analyses into astray.

When studying the development of risk-taking, one can see that Estonian managers' willingness to take risks had improved since the last Soviet year. Estonian managers believe positive development to continue and their willingness to take risks to be 'good' by 1999. Whether risk-taking rises to this level in reality, too, or whether this is only an instance of wishful thinking, requires further study on the subject (e.g. Table 16).

Table 16: Willingness to take risks in management

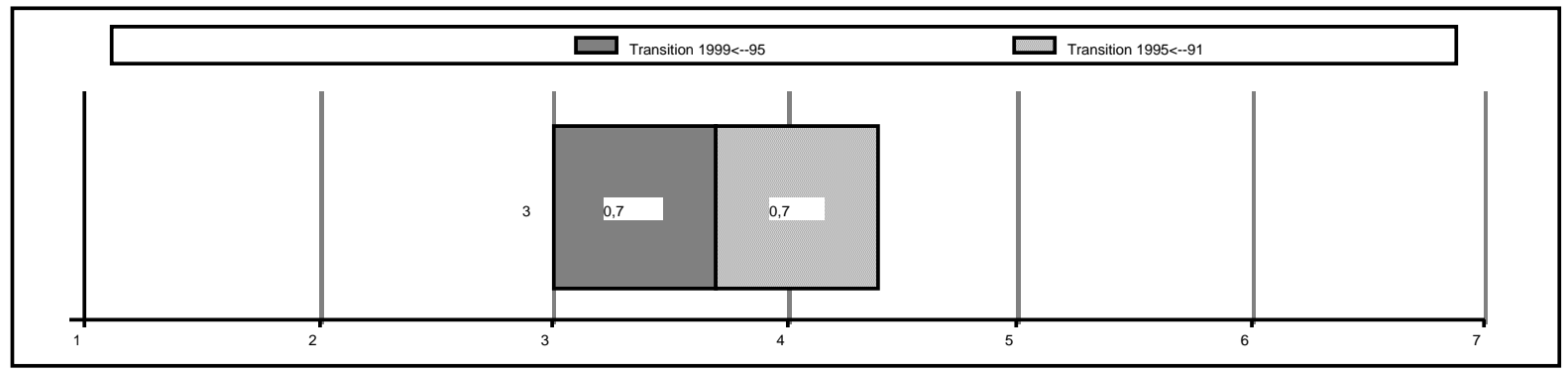

According to previous studies, Soviet organisational behaviour typically included clearly defined organisational hierarchy and job descriptions. The estimates given by these Estonian managers give a contrary view on clear division of work. In this context, however, one should remember that the last Soviet year was extremely turbulent and most likely to have confused operations in Estonian companies. Therefore, the observations of 1991 should not be applied to the Soviet era on the whole.

The results indicate clear development between the last Soviet year and 1995. The transformation pace is expected to remain similar during the latter half of this decade when this subarea would be at a better level than 'good' in 1999. Managers' tasks will become more specified probably because Estonian enterprise management has experienced a turbulent time, which is expected to settle by the end of this decade.

The answers of the Estonian managers indicate that the independence of managers was not considered poor during the last Soviet year. When analysing the managers' independence, one can notice that three per cent of the managers believed independence would diminish from 1991 to 1999. These managers had operated already during the Soviet era. This supports the assumption that a Soviet manager was able to operate more freely than is usually imagined ${ }^{6}$.

${ }^{6}$ Granick (1960:161-162) claims that „despite all the formal centralization, the individual plant director in Russia [the Soviet Union] seems to be much more successful in building his own little empire than his counterpart in the American giant corporation". 
Interestingly, the independence of managers is given one of the best estimates in 1999. The increasing independence in Estonian management is natural since several earlier studies have highlighted the importance of independent activity for the Estonians ${ }^{7}$. The emphasis on independence is one indication of the pace with which the Estonian management culture is outstripping the stagnant Soviet organizational behaviour.

According to the Estonian managers, the control of managers was not in the best possible state in 1995. This is understandable since the traditional control system is no longer functioning in these rapidly changing conditions. Control has especially diminished in state enterprises, which as such could be anticipated because, in general, the state cannot construct functioning systems of control at the same pace as private enterprises.

As a whole, positive in this transition is that the Estonian managers believe it to accelerate to some extent in the latter half of the 1990s. The Estonian managers expected the level of control to be 'good' by 1999. This positive direction may be due to the diminishing turbulence of the markets, which will enable enterprises to create functioning control systems by the end of this decade.

To summarise, the views of Estonian managers on organisational flexibility seem to reflect that Estonian organisations cannot be regarded as organisations where bureaucratic behaviour models would fundamentally impede the efficiency of operations (e.g. Tables 17, 18, and 19).

Table 17: The specificity of the managers' tasks

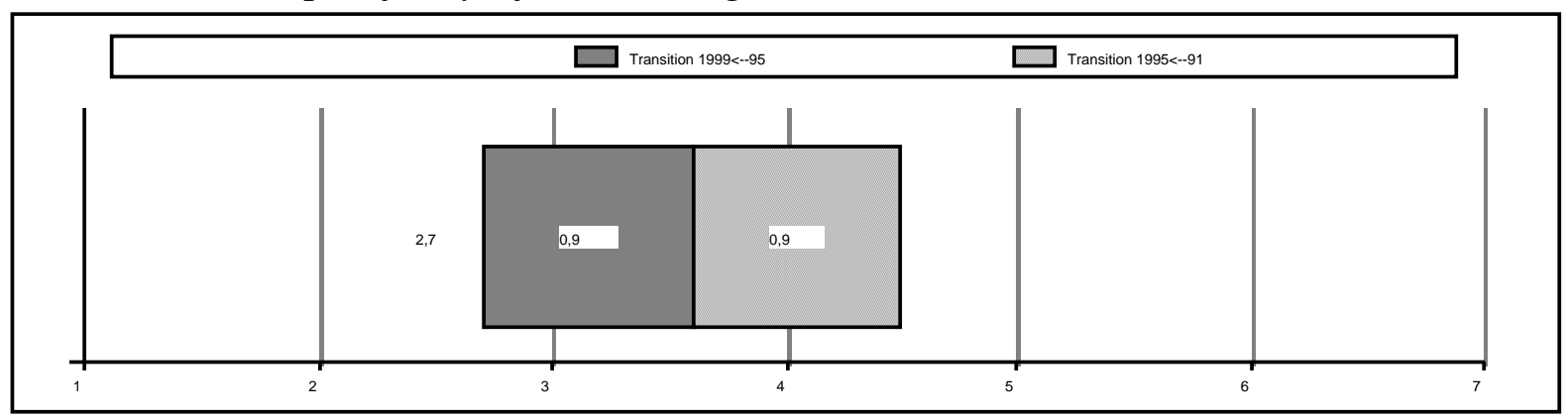

7 For example, see the following researches: Üksvarav / Nurmi (1993), Nurmi / Üksvarav (1994), and Vadi / Buono (1995). 
Table 18: The independence of managers

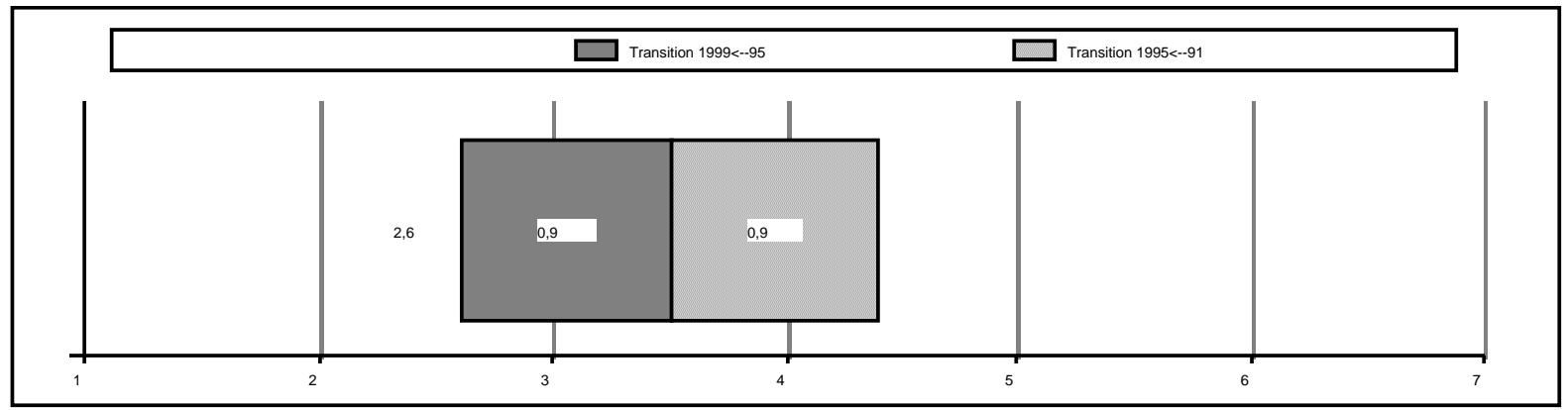

Table 19: The control of managers

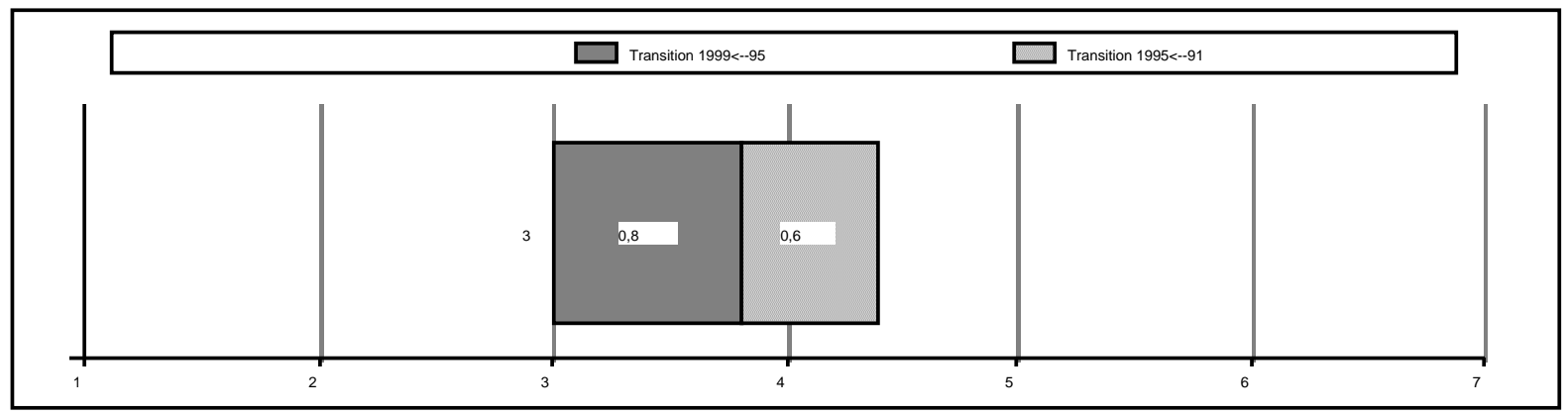

Relations between the Estonian managers were almost at the level of 'good' in 1995. In fact, the data suggest that the mutual relationships of managers were in a better state than other management areas studied. Even though these answers give evidence of a 'good' team spirit among the managers in 1995, the current situation is not due to transformation occurring faster than the average, but simply to the managers' relations being better than other subareas already in 1991. In fact, managers' relations have improved more slowly than other areas studied in this research.

This observation has a fairly significant methodological meaning. In other words, transformation study should not focus blindly on the pace of transformation, but also on the outcome of transformation. One needs to remember that a company already at a good level cannot improve its management as fast as a weaker company. As an illustration one can mention that a beggar can double his fortune much more easily than a multi-millionaire.

According to the Estonian managers, relations between managers and employees were not distinctively different from relations between managers. It is important to notice that these views were expressed by the managers. Had the employees been inquired, they might have answered somewhat differently.

If these answers are interpreted regardless of this restriction, they seem to sketch an extremely positive image of the state of the organisational climate. If this good climate actually prevails in Estonian companies, it most certainly provides them with a fairly healthy foundation for future transformation. 
The good state of organisational climate is also reflected in the flexible manner in which Estonian companies settled disagreements. To summarise the organisational climate, one can state that the Estonian managers were satisfied with its state. That the organisational climate had remained good and even improved is slightly unexpected because one might have expected the dismissals to have diminished the sense of solidarity among the personnel, created problems among them, and thus decreased employees' commitment to company goals and their motivation. However, the Estonian managers do not believe that this has happened. If the reality corresponds to these answers, this would be an illustration of the flexibility of Estonian employees (e.g. Tables 20, 21, and 22).

Table 20: Relations between the managers

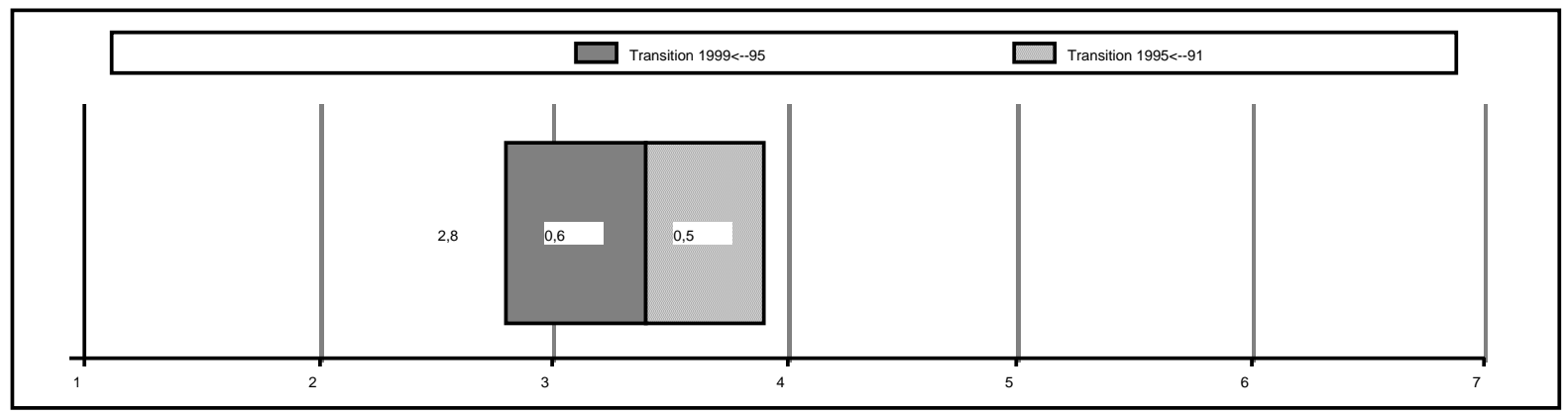

Table 21: Relations between the managers and the employees

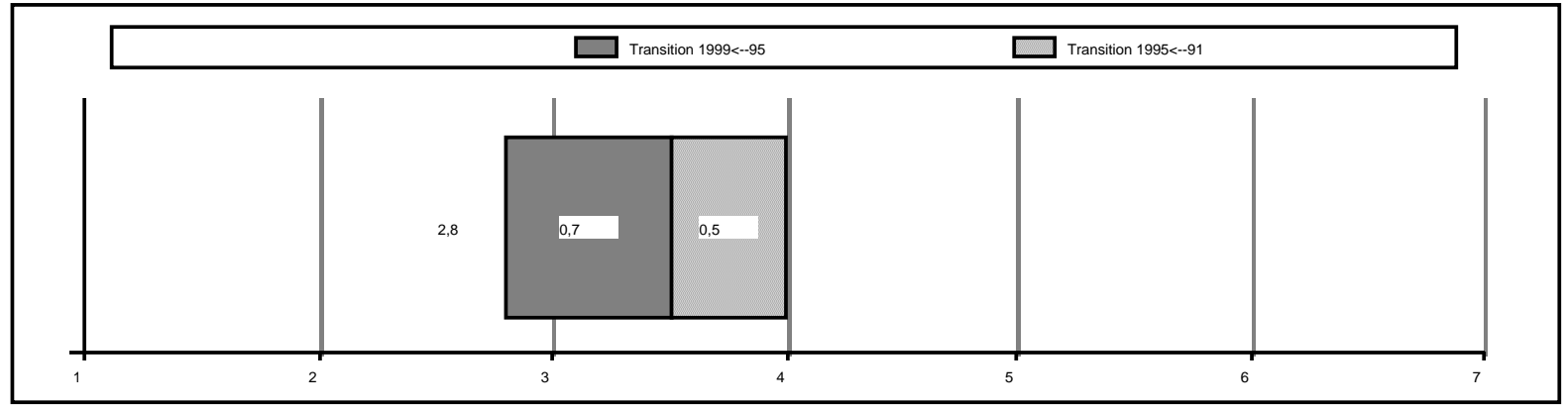

Table 22: Solving differences in opinions

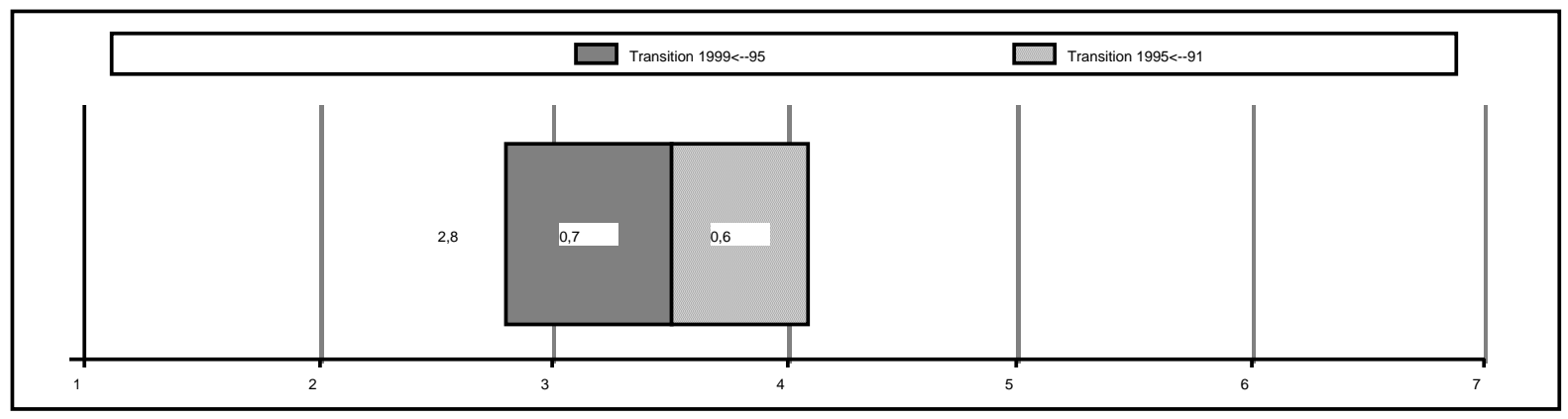

Contrary to previous research findings, the answers given by the Estonian managers do not indicate that the initiative of Estonian managers would have been poor in 1991. A possible explanation for this is the 'invisibility' of the managers' initiative. In other words, innovative skills were concentrated on how 
the company could, with least effort, meet its production requirements set by the state.

In fact, the management of the Soviet company demanded a lot of creativity as its business environment was in some turbulence, despite its stagnant official facade. This seemingly absurd argument simply stems from inflexible structures of the Soviet economy creating extreme uncertainty in the supply of goods and services. Operating in uncertain and imperfect economic conditions required a considerable deal of innovation, which could not be shown officially since it often failed to comply with the official regulations of the socialist system.

The Estonian managers believed the degree of initiative would improve in the future. These answers may be interpreted in various ways. First, this may signify the managers' increasing initiative within the organisation. Second, initiative may improve on account of more focus on the correspondence between initiative, business idea and strategies. Therefore, the improvement of initiative is not necessarily due to an increase in quantity, but to an improvement in quality.

The last two questions dealt with the capacity and will of the managers to change their practices. The answers given were rather surprising: the managers' capacity and will to change were given the poorest grades in 1995.

One might have imagined in advance that enterprise managers are the engines of transformation, the situation was nevertheless the opposite. One might begin to interpret these results by arguing that Estonian managers seem to react more to changes in their external managerial environment than actively strive to change the management of their companies.

The innovative skills, capacity and will of managers to change are of crucial importance for the future entrepreneurial and managerial transformation. If the Estonian enterprise managers, for some reason, fail to transform sufficiently rapidly, the Estonian companies face a difficult future with increasing competition (e.g. Tables 23, 24, and 25).

Table 23: The initiative of managers

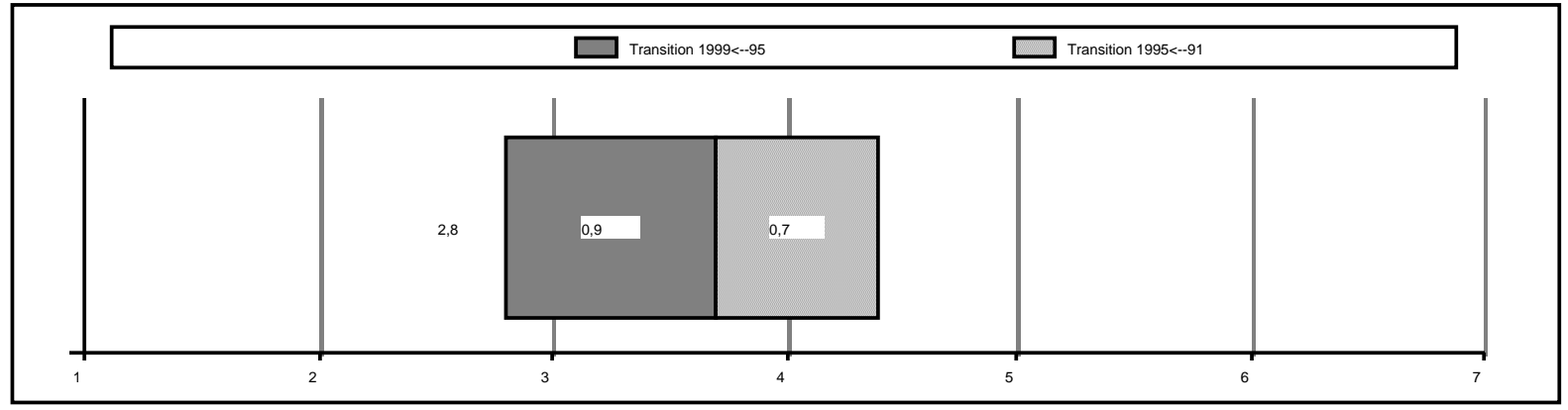


Table 24: Managers' capacities to change their practices

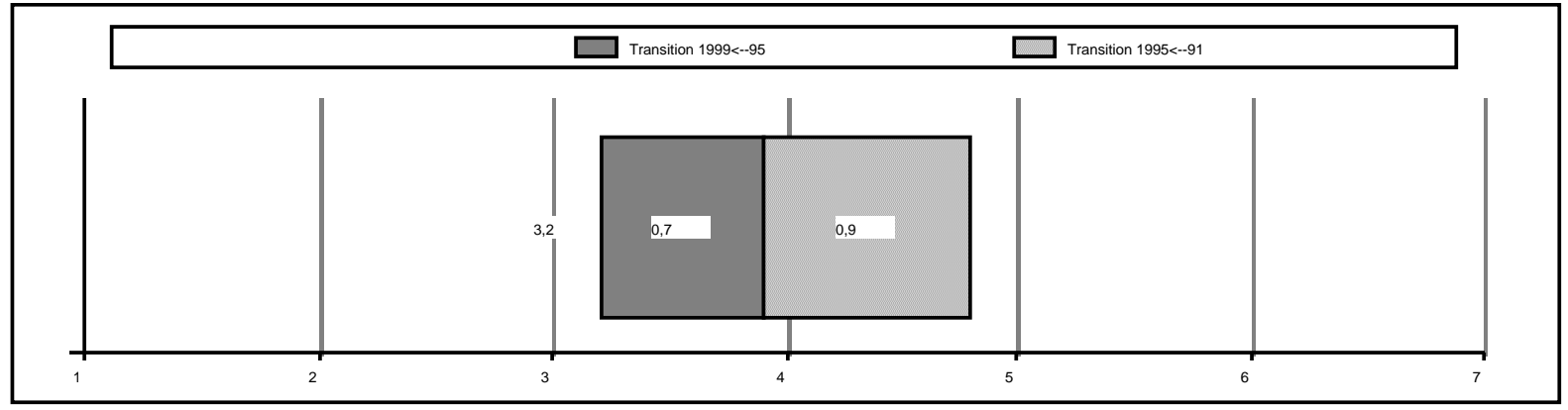

Table 25: Managers' will to change their practices

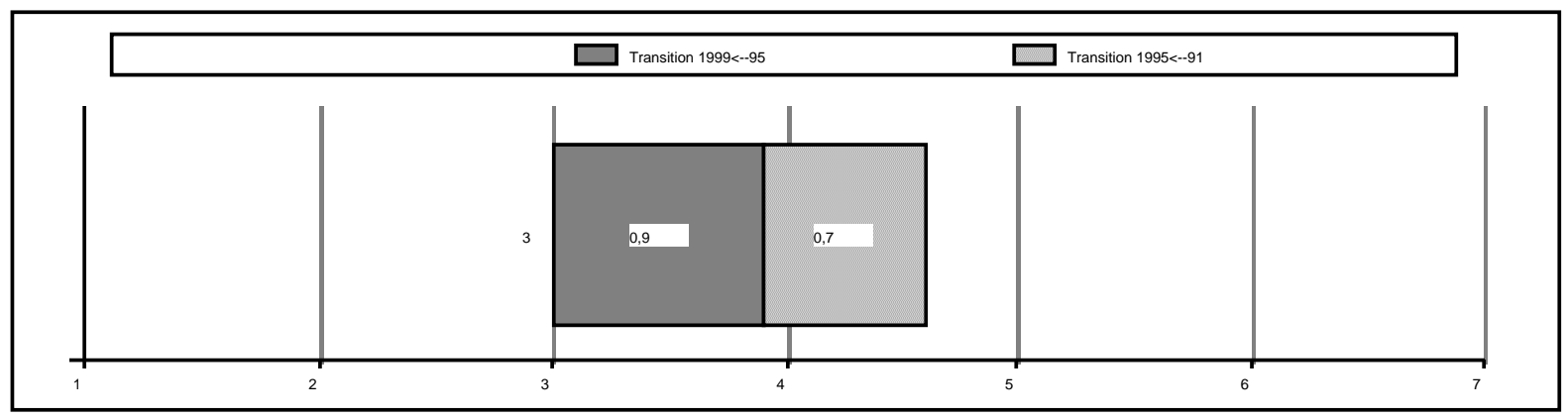

\section{Summary}

To summarise the transition of the managerial functions one can state that no major differences existed between the companies established during the Soviet era and after Estonian independence. Surprisingly, one could not discover many significant differences between various industries. Although the size of the sample should be larger in order to draw final conclusions, the data do not clearly support the assumption of industrial cultures and their different transformation pace. In this connection, one needs to remember that the statistics do not necessarily reflect the actual interaction of companies, which should act as the basis of defining subcultures. On the whole, the industrial subculture thinking should perhaps be compensated with a more functional alternative, such as 'the network cultures'.

A comparison of private enterprises with state-owned companies uncovered a very significant difference in 'cost-awareness in management'. The managers of state-owned enterprises felt more strongly than their colleagues in private companies that cost-awareness in their company had improved. The ultimate explanation for this is that during the planned economy state enterprises operated under the protection of state funding. The transformation finished softbudget constrain of the state companies and forced them to operate according to self-finance principles.

The small differences in the transformation between Estonian and foreignowned companies do not support the assumption that foreign companies were a self-evident driving force of transformation. One can argue that the main 
powers of the Estonian management transformation lay in the transition of national management culture. Foreign influences only provide the lubrication.

When comparing the companies with large personnel to those with small enterprises, one cannot notice that the management of small companies would transform more rapidly than large companies. This is rather unexpected since one might have anticipated that small units can develop their management faster than large companies. This surprising result might be explained by small companies lacking in sufficient financial resources to accomplish management transformation.

Managers ethnically Estonian or Russian expressed very different opinions in several issues. This result, however, can be only taken as referential because only a handful of Russian managers participated in this survey. Nevertheless, these very significant differences call for a further research on this subject.

On the basis of the research data, one may suspect significant improvement in Estonian enterprise management. The areas which have advanced most rapidly are market-orientation, strategic management and cost-awareness. In this context, it is necessary to point out that the poor starting point of these functions has largely accounted for their transformation pace being considerably faster. Correspondingly, the areas likely to develop most slowly were parts of organisational climate, the control of managers and risk taking (e.g. Table 26). 
Table 26: Summary of managerial transition in Estonia in 1991-99 (means)

\begin{tabular}{|llll|}
\hline & State in & State in & State in \\
& 1991 & 1995 & 1999 \\
1) The clarity of your company's business idea. & 4.4 & 3.5 & 2.7 \\
2) The accomplishment of the business idea. & 4.5 & 3.5 & 2.7 \\
3) The planning of company strategies. & 4.7 & 3.7 & 2.8 \\
4) The accomplishment of company strategies. & 4.7 & 3.8 & 2.8 \\
5) The control of the accomplishment of strategies. & 4.8 & 3.9 & 2.8 \\
6) The commitment of managers to company goals. & 4.2 & 3.5 & 2.5 \\
7) The motivation of managers. & 4.6 & 3.8 & 2.8 \\
8) Market-orientation in management. & 4.9 & 3.8 & 2.8 \\
9) Cost-awareness in management. & 4.7 & 3.7 & 2.8 \\
10) The training opportunities for managers. & 4.6 & 3.7 & 2.8 \\
11) The efficiency of the use of time by managers. & 4.5 & 3.9 & 2.9 \\
12) The planning system of decision-making. & 4.4 & 3.7 & 2.9 \\
13) The rapidness of decision-making. & 4.3 & 3.6 & 2.8 \\
14) The passing of information in your company. & 4.6 & 3.8 & 2.8 \\
15) The employees chances to influence in company. & 4.4 & 3.7 & 2.9 \\
16) Willingness to take risks in management. & 4.4 & 3.7 & 3.0 \\
17) The specificity of the managers' tasks. & 4.5 & 3.6 & 2.7 \\
18) The independence of managers. & 4.4 & 3.5 & 2.6 \\
19) The control of managers. & 4.4 & 3.8 & 3.0 \\
20) Relations between the managers. & 3.9 & 3.4 & 2.8 \\
21) Relations between the managers and the employees. & 4.0 & 3.5 & 2.8 \\
22) Solving differences in opinions. & 4.1 & 3.5 & 2.8 \\
23) The initiative of managers. & 4.4 & 3.7 & 2.8 \\
24) Managers' capacities to change their practices. & 4.8 & 3.9 & 3.2 \\
25) Managers' will to change their practices. & 4.6 & 3.9 & 3.0 \\
Averages & 4.5 & 3.7 & 2.8 \\
Maximum/minimum values & $4.9 / 3.9$ & $3.9 / 3.4$ & $3.2 / 2.5^{8}$ \\
\hline
\end{tabular}

One may state that the Estonian managers believe that most parts of management will be 'good' by the end of this decade. This does not necessarily mean that the management cultural transformation in Estonia would be over. One has to remember that enterprises which participated in this research can be regarded as a leading group in the transition of the Estonian enterprise sector. It

8 Although the differences between these factors are not great, the explanation for small differences is unlikely to be methodological bias. An indication of this is that with the same method one gathered managers' views on the external management environment of Estonia. The means of these answers differed from one another to a large extent. For instance, the maximum and minimum values of the external managerial environment were 5.8/4.4 in 1991, 4.7/3.8 in 1995 and 3.8/2.8 in 1999 (Liuhto 1996c). 
will take considerably more time from the main group of the Estonian enterprises to reach the same level as presented in this study.

Secondly, one has to emphasise that the research results are Estonian managers' estimations on their own management, and therefore, findings can offer a more rosy picture about the transition than the reality. Thirdly, the overall management cultural transformation is not over before managers' values and attitudes have transformed.

Finally, I believe it is vitally important to underline, with regard to the methodology applied in transformation study, that concentrating on the study of change alone may lead one's analyses astray. Results gained from the study of change indicate only the scale of the change, but not where the change has begun and where it has ended. For this reason, transformation study should focus on analysing two different periods and compare them to one another, rather than study the change alone.

\section{References}

Andrews, K.R. (1980): The Concept of Corporate Strategy. Richard D. Irwin, Inc. Homewood. Illinois.

Ariko, M.G. (1994): Tippijuht peaks olema loovan. Äripäev 31.08.1994. Tallinn.

Beissinger, M.R. (1988): Scientific Management, Socialist Discipline, and Soviet Power. Harvard University Press. Cambridge. Massachusetts.

Berliner, J.S. (1988): Soviet Industry: from Stalin to Gorbachev - essays on management \& innovation. Edward Elgar Publishing Company Limited. Aldershot.

Granick, D. (1960): The Red Executive. Doubleday \& Company. New York.

Kaubaleht (1995): Ettevôtlust rahastatakse oma taskust. Kaubaleht. 06.11.1995.

Kozminski, A.K. (1993): Catching Up? - Organizational and Management Change in the exSocialist Block. State University of New York Press. Albany.

Krips, H. (1992): Leadership and Social Competence in the Declining Years of Communism. Small Group Research. 23/1. pp. 130-145.

Lawrence, P.R. / Vlachoutsicos, C. (1990): Behind the Factory Walls: Decision Making in Soviet and US Enterprises. Harvard Business School Press. Boston.

Liuhto, K. (1991): The Interaction of Managerial Cultures in Soviet-Finnish Joint Ventures Including Estonian-Finnish Joint Ventures. Turku School of Economics and Business Administration. Institute for East-West Trade. Series B10/91. Turku.

Liuhto, K. (1993): Creating New Managerial Concept To Replace Management Sovieticus Managerial Transition in the former Soviet Union and Eastern Europe. Turku School of Economics and Business Administration. Institute for East-West Trade. Series B4/93. Turku.

Liuhto, K. (1996a): Entrepreneurial Transition in Post-Soviet Republics: Estonian Path. Europe-Asia Studies (formerly Soviet Studies). 48/1. pp. 121-140. 
Liuhto, K. (1996b): Estonian Enterprise Managers at the Gate of European Union. Management International Review - MIR. No. 3.

Liuhto, K. (1996c): The Transformation of External Management Environment in Estonia in the 1990s. To be published in 1996.

Milner, B. / Rapoport, V. / Yevenko, L.(1986): Design of Management Systems in USSR Industry: A Systems Approach. D. Reidel Publishing Company. Dordrecht.

Mintzberg, H. (1992): Forum: Learning in (and from) Eastern Europe. Scandinavian Journal of Management. 8/4. pp. 335-338.

Nurmi, R. / Üksvarav, R. (1994): Estonia and Finland: Culture and Management, A Conjectural Presentation. Turku School of Economics and Business Administration. Series A-9:1994. Turku.

Rue, L.W. / Holland, P.G. (1989): Strategic Management: Concepts and Experiences. Second edition. McGraw-Hill International Editions. New York.

Tung, R.L. (1986): Towards a Systems Model of Comparative Management. In: Advances in International Comparative Management, A research annual. Vol. 2. Ed. by Richard N. Farmer. JAI Press Inc. Greenwich. Connecticut. pp. 233-247.

Üksvarav, R. / Nurmi, R. (1993): Estonian Economy and Management in the Early 1990s. Turku School of Economics and Business Administration. Series A-4:1993. Turku.

Vadi, M. / Buono, A.F. (1995): Collectivism and Individualism in Estonia: An Exploratory Study of Societal Change and Organizational Orientation. In: Conference "MicroEconomic Transition”. Stockholm School of Economics in Riga. August 16-19, 1995. Riga. 